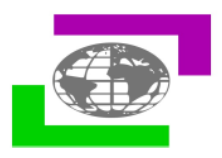

\title{
SULPHUR (GANDHAKA) PURIFICATION METHODS W.S.R. TO RASA CLASSICS
}

\section{Dr. Debasis Panigrahi}

Professor, Rasashastra \& Bhaishajya Kalpana, Faculty of Ayurvedic Sciences, Jayoti Vidyapeeth Women's University

Article Info: Received 10 November 2019; Accepted 20 December. 2019

DOI: https://doi.org/10.32553/jbpr.v8i6.698

Corresponding Author: Dr. Debasis Panigrahi

Conflict of interest statement: No conflict of interest

\section{ABSTRACT:}

Gandhaka is one of the materials that are in extensive use in the past and also in the present era. It can be equated with Sulphur in modern chemistry. All most all the Rasa literature have included it under UpaRasa group, however in the periodic table it belongs to $\mathrm{VI}-\mathrm{A}$. It has a great role mainly in the preparations of Rasa and Rasayana drugs. As such the material in crude form can't be used in drug manufacturing and therefore the crude materials are to be subjected to certain pharmaceutical measures to render them suitable for conversion into medicine and among such procedures the Shodhana is one. Historically Shodhana concept was in existence since the time of Smriti grantha Manusmriti and Charak Samhita ${ }^{1}(600-1000$ B.C) as while enumerating the fundamentals of Ayurvedic PharmaceuticsSaucha(Sudhhikarana) is found enumerated as one of the basic necessity for "Gunantaradhana"(alteration and/or addition of properties in the drugs). This concept was further developed after the development of Rasashastra. In the current article 18 classics of Rasashastra been explored and different Gandhaka Sodhana (purification) methods were analyzed and discussed elaborately.

Keywords: Gandhaka,Sodhana,Dhalana, Bhavana, Prakshalana, Mardana, Nirvapa,Swedana, Galana

\section{INTRODUCTION:}

Gandhaka is one of the member of UpaRasa by Rasa vagbhata found described in bible as brim stone. It was found indicated with the name of Lelitak in Kustha treatment in Charak Samhita and later Chakrapani has commented it as Pashana bheda. The sulphur is extensively used in Rasa Shastra especially in various mercurial operations. Shodhan - a concept of purification was existed and started as simple process since Smriti and Samhita literature was later flourished and included several processes into its fold. As such Shodhana can be compared with purification process, however when a drug was subjected to Shodhana following traditional methods the material is no longer retains original purity of the starting material.

There are several methods for the Shodhana of Gandhaka has been found mentioned in different texts. Among them the commonest method consists of heating of sulphur up to melting stage with ghrita on fire and then pouring through a cloth into cow milk taken in a container and then washing it with hot water. The process should be repeated for 3 to 7 times and every time taking fresh Dugdha and Ghrita.

Table 1: Showing Gandhaka Shodhana procedure \& media with reference

\begin{tabular}{|c|c|c|c|}
\hline Procedure & \begin{tabular}{|l|} 
No. of \\
methods
\end{tabular} & Media used for Shodhana & Reference \\
\hline $\begin{array}{l}\text { Dhalana using Sthaliyantra } \\
\text { Dhalana in Karsha or Kundali Patra }\end{array}$ & 2 & $\begin{array}{ll}- & \text { Milk } \\
\text { - } & \text { Ghee, milk }\end{array}$ & Rasadhyaya $^{2}$ \\
\hline $\begin{array}{l}\text { Dhalana (7 times) } \\
\text { Bhavana } \\
\text { Bhavana, Prakshalana } \\
\text { Dhalana } \\
\text { Dhalana in milk and Bhavana in } \\
\text { other media }\end{array}$ & 5 & $\begin{array}{ll}\text { - } & \text { Karanja taila, Eranda taila, Goat milk, Dhatura swaRasa } \\
\text { - } & \text { Jalini seed, matsya pitta } \\
\text { - } & \text { Bhringaraja swaRasa, warm water } \\
\text { - } & \text { Bhringaraja swaRasa } \\
\text { - } & \text { Milk, ginger, Bhringaraja and Nimbu swaRasa }\end{array}$ & Rasarnava ${ }^{3}$ \\
\hline
\end{tabular}


Melting \& pouring (Laghu putta). Melting \& pouring, Bhavana \& Drying (Two times).

Bhavana, Dhalana, Melting \& pouring (Mriduputa), Bhavana ( 3 times) Bhavana (7times each), Prakshalana, Shuskikarana, Dhalana.

Bhavana, Dhalana (7 times)

Bhavana, melting \& pouring (Laghu puta), Bhavana, melting and pouring, Bhavana (7 times), Mardana Bhavana (7 times), Prakshalana, Dhalana Bhavana, Dhalana (7times) Patana method Bhavana \& Dhalana (3 times)

\begin{tabular}{|l|l|} 
& 1 \\
\hline Melting \& pouring & 2
\end{tabular}

\section{Nirvapa}

Swedana in dolayantra,

Prakshalana, Dhalana

Dhalana

Nirvapa / swedana in dola yantra (7 times)

Dhalana \& swedana

Dhalana \& swedana (7 times)

Melting \& pouring

Melting \& pouring, Prakshalana

\begin{tabular}{|l|l|}
\hline $\begin{array}{l}\text { Dhalana in kurmaputa } \\
\text { Dhalana } \\
\text { Bhavana }\end{array}$ & 3 \\
\hline Swedana & \\
\hline
\end{tabular}

\begin{tabular}{|l|l|}
\hline Swedana & 1 \\
\hline $\begin{array}{l}\text { Laghu puta } \\
\text { Dhalana }\end{array}$ & 2 \\
\hline
\end{tabular}

\begin{tabular}{|l|l|}
\hline Dhalana & 2 \\
\hline Dhalana & 1
\end{tabular}

\begin{tabular}{|l|l|}
\hline Dhalana & 1 \\
\hline Kachapa puta or kurma puta, & 1
\end{tabular}

\section{Prakshalana}

Swedana in dola yantra, Prakshalana

Melting \& pouring

Nirvapa / swedana in dola yantra (7 times)

Laghu puta, Dhalana.

\section{Dhalana}

Swedana \& Dhalana

Dhalana

Dhalana / swedana (7 times)

Dhalana \& nirvapa

Melting \& aavapa (3 times)

Galana, dhalana (3 times for yoga

\& 5 times for sevana) is the

\section{- $\quad$ Ghee Milk}

- Kanguni/Sarshapa/Eranda/Kusumbha Tailam/Goat milk/Ghrita/Godugdha/Kanji, Dhatura swaRasa.

- $\quad$ Tilaparni, Ajamoda, Brahmi, Bhringaraja \& Dhatura swaRasa, Ghrita (equal quantity) and Aja dugdha, Godughda, Ghrita, Tilaparni SwaRasa, Matsyapitta, Jwalini bija churna, Bhringaraja swaRasa, Ghrita and Bhringaraja swaras.

- $\quad$ Brihati, Ajagandha, Bhringaraj, Dhatura \& Tilaparni drava,Ghrita (equal quantity) and Ajadugdha.

- Dhatura swaRasa \& Karanja taila, Eranda taila, Chhagidugdha, Dhatura swaRasa, matsya pitta, koshataki Bija churna, Bhringaraj swaRasa, Jala, Ghrita \& Bhringaraja swaRasa.

- Brahmi, Ajagandha, Bhringaraja, Dhatura or Tilaparni Rasa, Ghrita and Meshidugdha.

\section{Anandakanda ${ }^{4}$}


Dr. Debasis Panigrahi et al. Journal of Biomedical and Pharmaceutical Research

\begin{tabular}{|c|c|c|c|}
\hline \multicolumn{4}{|l|}{ Galana, dhalana (50 times) } \\
\hline Bhavana, dhalana, prakshalana & 1 & - $\quad$ Ghrita, Milk, Bhringaraja swaRasa & Rasamritam $^{20}$ \\
\hline $\begin{array}{l}\text { Dhalana (3 times), Prakshalana } \\
\text { Melting \& pouring } \\
\text { Dhalana, Prakshalana } \\
\text { Dhalana (7 times) } \\
\text { Damaru yantra paka (Patana) } \\
\text { Galana Aavapa, sedimentation, } \\
\text { shushkikarana }\end{array}$ & 6 & $\begin{array}{ll}\text { - } & \text { Ghrita(equal quantity), milk } \\
\text { - } & \text { Ghrita, milk } \\
\text { - } & \text { Sarshapa taila/ kusumbha taila (equal quantity), milk } \\
\text { - } & \text { Bhringraja swaRasa } \\
\text { - } & \text { No media } \\
\text { - } & \text { Churnodaka, lavanadravaka }\end{array}$ & Rasa Tarangini ${ }^{21}$ \\
\hline
\end{tabular}

Table 2: showing Procedures referred by various classics

\begin{tabular}{|c|c|c|c|c|c|c|}
\hline $\begin{array}{l}\text { Procidure } \rightarrow \\
\text { Reference } \downarrow\end{array}$ & Dhalana & Swedana & Bhavana & Patana & Aavapa & $\begin{array}{l}\text { Mishrita } \\
\text { (Mixed } \\
\text { procedures) }\end{array}$ \\
\hline Rasadhyaya & + & & & & & \\
\hline Rasarnava & + & & + & & & \\
\hline Anandakanda & + & & + & + & & + \\
\hline Chakradatta & + & & + & & & \\
\hline Rasa Paddhati & & & & & + & + \\
\hline Rasendra chudamani & + & + & & & + & \\
\hline Rasa Ratna Samucchaya & + & + & & & & + \\
\hline Rasa prakash sudhakara & & & & & & + \\
\hline Rasendra chintamani & + & & + & & & \\
\hline Rasa kamadhenu & & + & & & & \\
\hline Rasendra sara samgraha & + & & & & & Laghu Puta \\
\hline $\begin{array}{l}\text { Sharangadhar samhital Bhava } \\
\text { prakasha }\end{array}$ & + & & & & & \\
\hline Ayuveda prakash/Yoga ratnakar & & & & & & $\begin{array}{l}\text { Kacchapa } \\
\text { /Kurma Puta }\end{array}$ \\
\hline Br. Rasa Raja sundara & & + & & & + & + \\
\hline Rasa chandanshu & + & + & & & & Puta \\
\hline Rasayana sara & + & & & & + & Galana \\
\hline Rasamritam & + & & + & & & \\
\hline Rasa Tarangini & + & & & + & + & Galana \\
\hline
\end{tabular}

From the above Table, it can be summarized that Rasashastra classics have adopted following 6 types of methods (procedure) for Gandhaka Shodhana.

\section{Dhalana}

In this procedure, there are also two sub procedures- a) By melting Ashuddha Gandhaka in container and pouring immediately in container having milk, etc liquid. This procedure is termed as 'Dhalana' in above table. This procedure has been mentioned first by Chakradatta. Later this Patha from Chakradatta is also adopted by Rasendra sara samgraha $^{22}$ in Amlapitta Chikitsa Prakarana. The second procedure of Gandhaka Shodhana of Rasa ratna samucchaya has also get mention by authors of Ayurveda prakash, Rasendra purana, Br. Rasa raja sundara, Rasa chandanshu and Rasa jala nidhi.

Use of different liquids and Sneha drava in Gandhaka Shodhana have been first mentioned in Rasayana Sara.

Almost all authors use Lauhapatra for melting of Gandhaka, while Kanta Patra used by Anandakanda, Lauhapatra \& Hansatika by Rasa Taragini and Katah, Darvi \& Mritpatra by Rasayana Sara. Almost all authors quoted 'Sthali' or 'Bandha' as a container and used 'Kharpara' or 'Shravaka' above Gandhaka \& 'Vanyopala' as fuel.

b) By giving Laghuputa, melting, and self pouring of Gandhaka through a cotton cloth into the container having Dugdha etc. liquid in it. This 
procedure is here mentioned by the term 'melting \& pouring'. This procedure has been mentioned first by Anandakanda and Rasa prakasha sudhakara.

For Puta, author of Rasa prakasha sudhakara used 20 Upalas and the number of Upalas was mentioned for the first time. How much time heat should be given has been mentioned first by Rasadhyaya as 'Jwalayet ghatika dvayam'. Author of Rasendra Chintamani termed Laghuputa as 'Kurmaputa' and used Kanji instead of Dugdha first. The mouth of liquid containing container has been tied by woolen cloth by Rasa paddhati.

\section{Swedana}

In this method, Dolayantra has been recommended for Gandhaka Shodhana. By making Pottali of Ashuddha Gandhaka in cloth, do Swedana in Dolayantra containing liquids like Dugdha, Vasa, Sneha, Rakta, etc. This method is first depicted by Rasendra chudamani. Rasa manjari ${ }^{23}$ only mentioned Dugdha for Swedana.

It is not so common method for Gandhaka Shodhana. Instead of Pranij Dravya, author of Rasa dhatu prakash ${ }^{24}$, used Audbhida swaRasa as Nimba swaRasa/ Bhringaraja swaRasa for swedana of Gandhaka.

\section{Bhavana}

This procedure of Gandhaka Shodhana is first depicted by Rasarnava.

\section{Patana}

In this procedure, Damaru yantra has been used for Gandhaka Shodhana. It is first quoted in Ananda kanda and later in Rasa tarangini. For this, the author advised to make a fine powder of 4 pala. Gandhaka, placed it in a lower container of Damaru yantra and do paka for 4 Yama. Then, after cooling, evaporated Gandhaka crystals scraped from the upper container. This Shuddha Gandhaka is devoid of Pashanadi doshas.

\section{Aavapa}

This procedure is also depicted first by Rasa Tarangini. For this, take Sudhajala 13 parts and Ashuddha Gandhaka 2 parts, melt them till Gandhaka become 'Kapilabha varna', and then filtered it by cloth and place in glass container.
After cooling, do Aavap of Lavanadravak till Gandhaka gets settled. Then the liquid spilled out and do Prakshalana of Gandhaka, dry and powder it.

These Patha of Patana and Aavapa is then only mentioned by Rasa dhatu prakasha ${ }^{25}$.

\section{Mishrita (Mixed procedures)}

From the above procedures, Anandakanda, Rasarnava, and Rasa ratnakara have mentioned mixed procedures i.e. 2, 3 or 4 procedures for Gandhaka Shodhana. These mixed procedures seem to be useful in Dhatu vada.

From all these Gandhaka Shodhana procedures, nowadays the most common method generally adopted practically and commercially, is the $1^{\text {st }}$ procedure of Dhalana i.e. Dhalana followed by galan.

\section{INSTRUCTIONS REGARDING GANDHAKA SHODHANA BY DHALANA PROCEDURE}

\section{Gandhaka}

Before melting Gandhaka, it should be powdered first as 'Rajawata according to Chakradatta, Ayurveda prakasha, Rasa tarangini, Rasa ratna samucchaya, and Rasendra chintamani.

\section{Patra}

Almost all Rasashastra classics mentioned Lauha patra for Gandhaka melting. Anandakanda has used Kantapatra. Especially Lauhapatra having broad base should be used. Tamra patra should be avoided.

\section{Agni}

Use of Mridu agni instructed for the melting of Gandhaka, Gandhaka should be melted upto 'Tailanibha' according to Rasadhyaya, Rasa chandanshu, Rasa tarangini, and Rasendra sara samgraha.

\section{Sneha}

Karanja, Eranda, Sarshapa, Tila, Kusumbha, Bhallataka, Jayapala \& Bibhitaka taila, and Ghrita should be used as Sneha dravya according to Rasarnava, Rasa ratnakar, Rasa tarangini, and Rasayana Sara. Generally, Ghrita should be used. 


\section{Sneha matra}

Regarding Sneha matra got following 5 instructions

a. Melting of Gandhaka without Sneha is instructed by authors of Chakradatta, Rasendra Sara samgraha, Ayurveda prakash, Rasendra purana, Br. Rasa Raja Sundara, Rasa dhatu prakash and Rasa chandanshu.

b. Melting of Gandhaka in Ghritayukta patra is mentioned by Rasarnava, Anandakanda, Rasa ratnakara, Rasadhyaya and Rasamritam.

c. Equal quantity of Sneha is used by Anandakanda, Rasa ratna kara, Rasendra chudamani, Rasa kama dhenu (Rasa sara), Rasendra sara samgraha, Rasendra chintamani, Sharangadhara samhita, Rasendra bhaskara, Rasa dhatu prakash, Rasa chandanshu,Ayurveda Prakash, Bhava prakash, and Rasa Tarangini.

d. $1 / 4^{\text {th }}$ Sneha for Gandhaka dravana has been quoted by Rasayana Sara.

\section{Drava}

Besides Dhatuvada Granthas, mostly Dugdha and then Bhringaraja swaRasa is indicated.

a. Dravya Matra - Instruction of Dravyamatra has not mentioned generally in all classics expect Rasayana Sara, here 2 times of Drava (of Gandhaka) is indicated.

b. Dravavastha - According to PRasadini Sanskrit commentary on Rasa tarangini ${ }^{26}$, the drava i.e. Dugdha should be taken hot. If taken cold, the dugdha and ghrita enter into pores of Gandhaka making it flavored (Gandhayukta).

\section{Vastra}

Rasashastra classics instructed to use 'Tanu vastra'.

\section{Dhalana matra}

Rasarnava, Rasa Ratnakar, Ayurveda Prakash, Rasa tarangini, Rasamritam, and Rasayana Sara have instructed Dhalana of Ghandhaka (melted) once or thrice and for internal administration, Dhalana should be done 3,5 or 7 times. According to Ayurveda prakasha and Rasa tarangini, Drava should be taken fresh each time.

\section{Prakshalana}

Ayurveda prakasha and Rasa tarangini instructed Prakshalana by water (hot) after Gandhaka Shodhana.

\section{Note}

Before Shodhana of Gandhaka, to remove its physical impurities like dust, etc. it should be washed with Nimbu swaRasa. Like Gandhaka, Tankana should also be washed, as per Rasendra chintamani ${ }^{27}$.

After delving through the Rasashastra classics, we can find that particular Gandhaka Shodhana procedures have also been mentioned randomly for preparation of particular formulations, besides under heading 'Gandhaka Shodhana'. As per Chakradatta $^{28}$, for the preparation of Rasa parpati, Parada and Gandhaka Shodhana should be done which is mentioned in Kshudhavati Gudika preparation in Amalpitta Chikitsa Prakarana In this context, Bhaishajya ratnavali ${ }^{29}$ also suggests special Gandhaka Shodhana procedure for preparation of Rasa parpati. In this method, Gandhaka is subjected to 7 bhavanas of Bhringaraja swaRasa, dry \& powder it. Then by melting, pour into Bhringaraja swaRasa once, dry in sunlight and make churna like Ketakirajasa, melting done on 'Badarakasthangara'.

In this way, Rasendra chintamani ${ }^{30}$ also mentions 'Rasa shodhita Gandhaka' for the preparation of Br. Somnatha Rasa (Bahumutra Soma Rogadhikara). As per Vaidya Maniram Sharma, ('Maniprabha' Sanskrit commentary on Rasendra chintamani) - 'Mushakpani Rasen Shodhito Gandhakah'.

\section{Discussion:}

Literature regarding the Shodhana reveals that Rasashastra classics have adopted 6 types of procedures.viz. Dhalana, Swedana,Bhavana, Patana, Aavapa, and Mishrita (i.e. mixed procedures). Out of these, Dhalana procedure can also be divided into two types i.e. melting Ashuddha Gandhaka with Ghrita in a container and pouring in the container through cotton cloth smeared with Ghrita having Dugdha, etc. liquid which is the most common method. The classics have given scientific explanation stating that the 
poisonous principles associated with Gandhak will bound to ghee and the stones and gravel, sand etc get disassociated and remained in cloth. Second Dhalana procedure mentioned, by giving Laghuputa, involving melting and self pouring of Gandhaka through the cotton cloth into the container having liquid in it. The former one is the contribution of Chakradatta and later's is of Anandakanda and Rasa Prakash Sudhakara.

Besides under heading Shodhana, special methods of Gandhaka Shodhana have also been mentioned for preparation of particular formulation.

Mostly the media used for Gandhaka Shodhana, Anupana of Shuddha Gandhaka and dravya used for management of complications caused by Gandhaka Sevana quoted same as Godugdha and Goghrita. It shows that Rasacharyas wanted to slow down its 'Agnikari' guna and also to reduce its toxic or adverse effects. It also throws light on Rasahsastriya principles.

\section{Conclusion}

The process of Shodhana can be found in every Rasashastra classics which removes the physical, chemical impurities and reduces the toxic effects. Chemical impurities are eliminated through evaporation, dissolution and binding with ghrita, milk, whereas physical impurities are removed by filtering through the cloth. Though "Dhalana" method of Sodhana is very common, choice of the method of Shodhana is dependent on the potential usage of Gandhaka.

\section{Reference}

1. Charaka Samhita- Vimana sthana 1st chapter, Acharya Agnivesha, Edited by Kashinath Shastri,Chaukhambha Sanskrit series office, 1998, Varanasi

2. Rasadhyaya - of Acharya Kankalay Yogi, with Champakkrit Sanskrit Vivratti, edited by Pt. Ramakrishna Sharma and 'Rasaprabha' Hindi commenatry by Dr. Indradev Tripathi, Chaukhamba Sanskrit Sansthan, Varanasi, 2ndedition, 1982.

3. Rasarnava - $7 / 67-73$, edited by Dr. Indradev Tripathi with 'Rasachandrika' Hindi commentary, Chaukhamba Sanskrit Series Office, Varanasi, 2ndedition, 1978

4. Anandakanda by Sri Bhairava, Kriyakarana Vishranti, Prathama Ullasa, edited by Prof. S N
Mishra with Siddhi Prada commentary, Choukamba Orientalia, $1^{\text {st }}$ Edn.2008. Varanasi

5. Chakradatta by Acharya Chakrapani, 50 Amlapitta Chikitsa - 34-35, edited by Prof. Priyavrata Sharma, Swami Jayaramdas Ramprakash Trust Jaipur $1^{\text {st }}$ edition, 1999

6. Rasapaddhati of Sri Bindu Pandit edited by Acharya Siddhi Nandan Mishra,Chaukhambha Sankrit Pratisthan,2013,Varanasi

7. Rasendra Chudamani - 11/8-14 Acharya Somadeva with Siddhiprada Hindi commentary by Dr. Siddinandana Mishra Choukamba Orientalia Varanasi, $2^{\text {nd }}$ edition 1999.

8. Rasa Ratna Samucchaya - 3/20-25, of Rasa Vagbhata commented by Ambikadatta Shastri Chaukambha publication $9^{\text {th }}$ edition Varanasi 1995

9. Rasa Prakash Sudhakar - 6/34-36, of Yashodhara Bhatta with Siddhiprada Hindi commentary by Dr. Siddinandan Mishra, Choukamba Orientalia Varanasi $1^{\text {st }}$ edition 2004

10. Rasendra Chintamani -5/2-6, Dhundukanatha with Maniprabha commentary of Maniram Sharma, Samsodha by Vaidya Srinath Sharma: published by Vaidhya Manram Sharma, Ratangar (Rajasthan) $1^{\text {st }}$ edition 1933

11. Rasa Kama Dhenu, Vol. II - 4/43, compiled by Shri. Chudamani Mishra, translated by Gulraj Sharma Mishra, Chaukhamba Orientalia, Varanasi, $3^{\text {rd }}$ edition, 2007.

12. Rasendra Sara Samgraha - $1 / 125-128$, Shri. Gopal Krishna Bhatta, edited by Shri. Narendranath Mitra with 'Saralakhya' Hindi commentary by Pt. Vidhyadhara, Motilal Banarasidas, New Delhi, $4^{\text {th }}$ edition, 1976

13. Sharangadhara Samhita, Madhyam khanda 12/13-14, Pt. Sharangadharacharya with Adhamalla's 'Dipika' and Kashiram's 'Gudhartha Dipika' Sanskrit commentaries, Chaukhamba Orientalia, Varanasi, $4^{\text {th }}$ edition, 2000

14. Bhava Prakash, Purva Khanda, Dhatwadi Shodhana-Marana Vidhi Prakarana -Sh. 205-206, Shri. Bhava Mishra, Purva Khanda, edited and 'Vidyotini' Hindi commentary by Pt. Brahma Shankar Shastri, Chaukhamba Sanskrit Sansthan, Varanasi, $5^{\text {th }}$ edition, 1988

15. Ayurveda Prakash - 2/19, Acharya Madhav Upadhyay, edited with 'Artha Vidyotini' (Sanskrit) and 'Artha Prakashini' (Hindi) commentaries by Gulraj Sharma Mishra, Chaukhamba Bharti Academy, Reprint 1999.

16. Yoga Ratnakara, Gandhaka - Sh. 2 , P. 159, Sadashiv Shastri Joshi, Chaukhamba Sanskrit Series Office, Varanasi, $1^{\text {st }}$ edition, 1939. 
17. Br. Rasa Raja Sundara, Gandhaka Prakarana - P. 53, Pt. Dattaram Chaube, Gyan Sagar Press, Kishangarh (Raj.), $2^{\text {nd }}$ edition, 1984.

18. Rasa Chandanshu, Purva khanda -P. 42-44, Acharya Shridatta, edited and Marathi translation by $\mathrm{Vd}$. Datto Ballal Borkar, Shri. Gajanan Book Depot, Mumbai, $3^{\text {rd }}$ edition, 1983.

19. Rasayana Sara, Vol. I, Parada Prakaranam - P.96104. Shri Shyamsundaracharya Vaishya, Chaukhamba Krishnadas Academy, Varanasi, $7^{\text {th }}$ edition, 2005.

20. Rasamritam - $2 / 3$, Yadavji Trikamji Acharya, Motilal Banarasidas, Varanasi, $1^{\text {st }}$ edition, 1951.

21. Rasa Tarangini - 8/7-31, P. 176-180, Shri Sadananda Sharma with 'PRasadini' Sanskrit commentary by Shri Haridatta Shastri and 'Rasa Vigyana' Hindi commentary by Pt. Dharmananda Shastri, edited by Shri Kashinath Shastri, Motilal Banarasidas, New Delhi, $11^{\text {th }}$ edition, Reprint 2000.

22. Rasendra Sara Samgraha, Amlapitta Chikitsa Sh.17,18, Shri. Gopal Krishna Bhatta, edited by Shri. Narendranath Mitra with 'Saralakhya' Hindi commentary by Pt. Vidhyadhara, Motilal Banarasidas, New Delhi, $4^{\text {th }}$ edition, 1976

23. Rasa Manjari - $3 / 8,9$, Acharya Shalinath, edited by Prof. S. N. Mishra, Chaukhamba Orientalia, Varanasi, $1^{\text {st }}$ edition, 1995.
24. Rasa Dhatu Prakash, Part I, Cha.41 - P.454, Vd. P. D. Mule, Part I, Ananta Mudranalaya, Amravati, $1^{\text {st }}$ edition, 1956.

25. Ibid, Part I, Cha.41 - P.455, Vd. P. D. Mule, Part I, Ananta Mudranalaya, Amravati, $1^{\text {st }}$ edition, 1956.

26. Rasa Tarangini, 8 th Tarang, Sanskrit Tika on Sh. 712 - P.176,

27. Rasendra Chintamani - 5/1, Shri. Dhundhukanath with 'Mani Prabha' Sanskrit commentary of Shri. Maniram Sharma, Shri. Dhanwantari Mandir, Ratangarh (Raj.), $1^{\text {st }}$ edition, 1933.

28. Chakradatta, Grahani Chikitsa - 4/86, Chakrapanidatta with 'Ratna Prabha' Sanskrit commentary by Shri. Nischalakara, edited by Prof. Priyavrat Sharma, Swami Jayaramdas Ramprakash Trust, Jaipur, $1^{\text {st }}$ edition, 1993.

29. Bhaishajya Ratnavali, Grahani Chikitsa - Sh. 304305, Shri Govindadas Sen, Hindi commentary by Shri. Ambikadatta Shastri, Chaukhamba Sanskrit Sansthan, Varanasi, 1993.

30. Rasendra Chintamani - 9/18, Shri. Dhundhukanath with 'Mani Prabha' Sanskrit commentary of Shri. Maniram Sharma, Shri. Dhanwantari Mandir, Ratangarh (Raj.), $1^{\text {st }}$ edition, 1933. 